\title{
THE ACTIVITIES OF FACTORY «PROWODNIK» IN RIGA AND ITS EMPLOYEES - GRADUATES OF THE RIGA POLYTECHNICUM / RIGA POLYTECHNIC INSTITUTE
}

ALİDA ZIGMUNDE*

Riga Technical University

OL̦EGS ŠAPOVALOVS

«Prowodnik» Museum of Riga Electromachine Building Factory

\begin{abstract}
Summary. The article gives an overview of the activities of rubber, gutta-percha and telegraph factory «Prowodnik» in Riga, founded in 1888. Before the First World War, the factory was one of the four largest rubber factories in the world. During the First World War, in 1915, the factory was evacuated to Moscow, in 1918, it was expropriated. In 1921, the shareholders decided to re-establish «Prowodnik» in its old premises in Riga, but the economic situation had changed. For some years it operated as a woodworking factory (1925-1935), but it never reached the boom it had experienced at the end of the 19th century and at the beginning of the 20th century. At the end of the 1930s the factory was liquidated. The alumni of the Riga Polytechnicum (RP) and Riga Polytechnic Institute (RPI) who had given significant input in its achievements have been identified by the authors of this article.
\end{abstract}

Keywords. «Prowodnik», Riga Polytechnicum, Riga Polytechnic Institute, alumni in industry.

\section{Factory «Prowodnik» - the largest factory of rubber production in Riga (1888-1915)}

In the 1980s, rapid industrial development began in Riga, Liepāja, Jelgava and other major cities of Czarist Russia. Newly-established factories and stock companies, including factory «Prowodnik»- Russian-French

\footnotetext{
* Corresponding author.

E-mail: alida.zigmunde@rtu.lv Alida.Zigmunde@rtu.lv
} 
company producing rubber, gutta-percha and telegraph equipment established on 26 June $^{1} 1888$, needed thousands of workers, as well as engineers [1]. Before that, in 1864, the J. V. Muendel Rubber Factory, which was located in Pārdaugava, already operated in Riga. Although many villagers moved to the city at that time, industrial firms did not offer them adequate salaries. This is why workers from Lithuania, Poland, Belarus and other regions of Russia were invitated. Announcements offering jobs in Riga were even placed in public places in Siberia, and the large factory «Prowodnik» was «the most active in this respect [2].»

The rubber, gutta-percha and telegraph factory «Prowodnik» of the Russian-French company started production and construction of buildings in Sarkandaugava at 31 Ganību Embankment, occupying an area of 13700 square meters. The production started in 1889 and both the operation and new buildings were expanded. At the beginning the fixed capital of the factory was 0.7 million rubles, later it gradually increased, except during the crisis years at the end of the 19th century, and on 1 January 1909, it reached 9 million rubles [3]. The factory produced rubber overshoes, and as the demand was high, their production volumes increased. There was time when 45000 pairs of these shoes were made per day; in fact, in 1907, about 3500 workers worked in the production workshops of the factory [4]. In addition, tires for automobiles, aircraft and bicycles, as well as electrical products, rubber and technical products for medicine, insulating materials, cable accessories, linoleum, toys, telegraph equipment, light pontoons, diver suits and other products were manufactured.

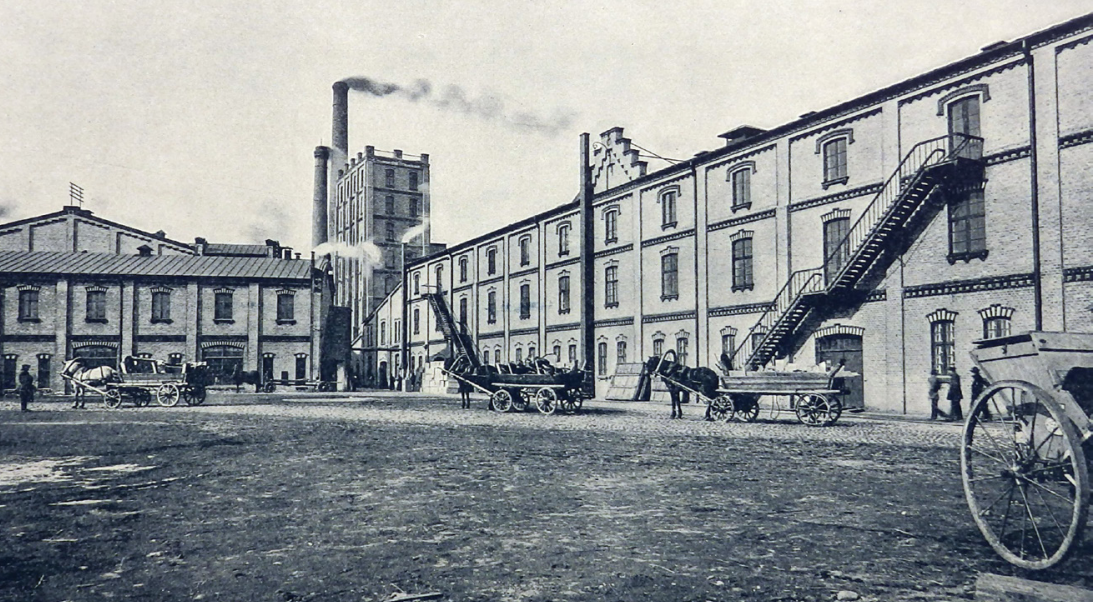

Figure 1. Factory yard at the rubber shoes warehouse, beginning of the 20th century [4].

1 After the July calendar (old style), after the Gregorian calendar (new style) - 8 July. 
Raw materials were imported and $95 \%$ of the produce was sold in Russian markets. The factory had warehouses and representative offices in the cities of Russia, present-day Azerbaijan, Iran, China, Poland, Finland, Ukraine, Uzbekistan and in the cities of other countries such as Ashgabat, Astrakhan, Baku, Berlin, Częstochowa, Daugavpils, Gomel, Harbin, Kharkiv, Helsinki, Ekaterinburg, Ekaterinoslav, Irkutsk, Kaunas, Kazan, Kiev, Kokanda, Kremenchuk, Liepāja, Łódź, London, Margilona, Moscow, Minsk, Mykolaiv, Nizhny Novgorod, Odessa, Omsk, Orenburg, Orl, Paris, Perm, Pskov, Rasht, Rostov-on-Don, St. Petersburg, Samara, Samarqand, Saratov, Smolensk, Sosnowica, Stockholm, Shanghai, Tallinn, Tashkent, Teheran, Tbilisi, Tver, Warsaw, Vilnius, Vitebsk, Vienna, Vladivostok, Volgograd, Voronezh [5]. The «Prowodnik» production was also bought in England, Germany, and some of it also in the countries over the ocean [6]. In addition, the factory performed orders of the Russian Imperial Court and was one of the four largest rubber factories in the world before the First World War. The production was of a very high quality and known in the world, so it was in demand [7].

To produce such a large volume, employees were needed. In 1889, there were 650 workers in «Prowodnik», but before the First World War it was about 14000 . The workers were of different nationalities. For example in 1897, out of 2775 employees there were 1267 Latvians, 1254 Lithuanians and Polish, 177 Russians, 59 Germans, and 18 Estonians [8]. By the way, guest workers who were invited to Riga were significantly holding down Latvian workers' salaries [9], which could also significantly lower the prices for rubber products, linoleum and other goods. Salaries were the reason for economic strikes. For example on 17 July 1913, 100 mechanics went on strike; on 18 July it was about 200 workers [10]. The strikes in the factory were quite common. Workers went to the streets already in the 1905 revolution and many were killed. Later, sculptor Kārlis Zāle devoted one of the bas-reliefs of the Freedom Monument to the revolutionaries of «Prowodnik».

The growth and success of the factory was impossible without skilful management, among them were a number of engineers who had studied in Riga. But there were also those who had not studied in Riga and came from other cities. One of them was a man born in the province of Vitebsk - Boriss Wittenberg (1867-1942), who arrived in Riga and began to work in 1890 . He completed a course in commerce in Moscow (1897) and in 1900 became Executive Director of the factory, but in 1906 - Director General and Chairman of the Board [11]. The factory had various problems at that time, but B. Wittenberg continued to develop it, expanding it to the world level. Occasionally, there were accidents at the factory, because workers did not always comply with safety regulations. All factory workers were insured against accidents, and medical 
care was well organized. There was a lazaret with twenty beds in the factory. There were two doctors and a feldsher. In addition, the factory had a contract with a private surgical clinic, which accepted the patients from the factory if necessary. The treatment expenses were covered by «Prowodnik».

Between 1906 and 1914, under the guidance of Boriss Wittenberg, a nursery, a children's shelter, houses for factory, baths, a workers' club, and a garden with a musical pavilion (next to the Sarkandaugava station) was built in Sarkandaugava. For the workers of «Prowodnik» all services were free of charge. In 1906, the newspaper «Balss» («Voice») wrote: «If we calculated the expenditures of «Prowodnik» for the treatment of workers and their relatives, it would turn out that the Board of the Association spends about 175000 rubles a year for workers [12].»

The first manufacturing building of «Prowodnik» was designed by the graduates of the Riga Polytechnicum Edmund von Trompowsky (1851-1919) and Jan Benedykt Wodzinski (1859-1926). Engineering science specialist J. B. Wodzinski also worked as a lecturer at the Riga Polytechnicum / Riga Polytechnic Institute. Two large warehouse buildings were built along the Sarkandaugava Canal. These were the first monolithic reinforced concrete structures in Europe - 266 meters long and 15 meters high, built by Swiss engineer Robert Maillart (1872-1940). They were built between 1913 and 1914. Part of the «Prowodnik» buildings have survived and are still used.

At the outbreak of the First World War, the Russian emperor Alexandra Fyodorovna (Александра Фёдоровна; 1872-1918) took care of the 50-bed hospital for the sick and wounded in the factory area [13]. The factory operation stopped when the war began. Part of the workers were mobilized, it was not possible to get raw materials and to deliver the produce to clients and warehouses, therefore the «Prowodnik» operation was stopped, but in 1915, the factory was evacuated to Moscow and only the buildings remained in Riga.

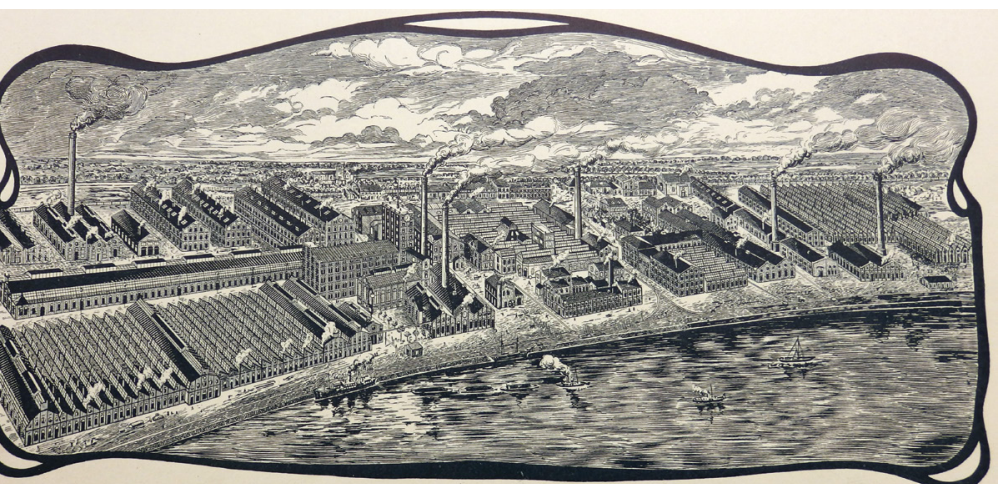

Figure 2. Factory «Prowodnik», overview, beginning of the 20th century [14]. 
In Moscow, three more factory buildings were built, and in 1917, the factory was restored. One of the graduates (1911) of the Department of Engineering of the Riga Polytechnic Institute Eduards Veiss (1886-1966) remembers: «There were 8000 workers in one newly built building of «Prowodnik», the turnover was 16 million rubles. Only the Rigans were accepted in the positions of heads of divisions and other important positions, if only they were available, because the owners of the company held that the Rigans had thorough knowledge, were good workers, were honest and not boastful [15].

\section{«Prowodnik» in inter-war period}

After the Latvian War of Independence, on October 21, 1920, five officials from «Prowodnik» had a meeting in Riga - directors Hugo Frey and Eugen Lindenberg, former nominee for a director's post Alexander Klee, and members of the Supervising Council Jakob Erhardt and Max Ruhtenberg [16]. It was decided to renew the operation of the factory in autumn 1921. Preparation works were carried out - equipment was ordered from France and raw materials ordered from America. On 26 May 1921, the general meeting of shareholders of «Prowodnik» took place during which it was unanimously decided to renew the factory in the nearest future and to the previous extent. B. Wittenberg, having extensive experience, was unanimously elected Chairman of the Council / Director General [17]. In 1921, the Statutes were approved as well [18]. B. Wittenberg met Prime Minister of the Republic of Latvia Kärlis Ulmanis (1877-11942) [19] and the Minister of Economics, graduate of RPI (1897) Ringolds Kalninšs (1873-1940) [20] and was convinced that the country was stable and safe. Shareholders from France were willing to invest a lot of money. The Latvian government supported such a decision because it knew about the success of the factory before the war, and if it were to be extended, then many people in the country would be employed. Boris Wittenberg wanted to get a concession to the «Prowodnik» properties in Moscow, which the Bolsheviks had nationalized. However, this did not succeed him, as did a trip to Moscow [21]. As machinery and equipment were left in Russia, some of the shareholder purchased Muendel Rubber Factory in 1922 and established a joint-stock company - Riga Rubber Factory «Kontinents» [22]. B. Wittenberg, the permanent Director General, did not work there. The Board of «Prowodnik» was based in Paris and its goal was to generate profit. It was not possible to completely renew the former factory and shareholders' opinions differed about its possible operation in Latvia, therefore they waited a little hoping that it would be possible to at least partly renew the production. 
Later, the administration was worried about the new customs tariff, so the factory did not start the production [23]. In 1924, newspapers published news that the factory was about to be bought by the Swiss [24]. The «Prowodnik» shareholders had opened a new factory «Askim» in Norway. It produced 2500 rubber overshoes per day and its produce was made for the Baltics and other European countries. The factory was headed by Erwin Koch, former director of «Prowodnik», there had been an intention to nominate him director in Riga [25]. But the situation had changed and the earlier rubber manufacturer in Latvia did not renew its activities in this area. Liquidation began in 1924; shareholders were identified as well as the amounts of their investments. Part of them resided in Riga, others - abroad. Among the shareholders were students and graduates of the Riga Polytechnicum / Riga Polytechnic Institute [26].

In 1925, a new timber production company «Prowodnik» was created instead of the factory that had been liquidated, which occupied only a part of the former «Prowodnik» buildings and territories. Some of former shareholders, including former Director General B. Wittenberg, who lived in France but often travelled to Riga, participated. It is known that the factory hired out free spaces, for example for the linen warehouse «Sovtorgflot» of Soviet Russia [27]. Several times fires broke out destroying the facilities, raw materials and production, as well as damaged the buildings of the factory. Although they were stone buildings, it was already in the 19th century, soon after the factory's opening, that the first fire broke out. The buildings were close to each other and did not have the walls defending from fire. The restored joint-stock company did not have a successful business, it got into debt and already in 1934 the premises were leased, but in 1935 the liquidation of the timber industry joint stock company «Prowodnik» [28], which was founded ten years ago, began, which lasted until 1940. Some buildings were demolished, bricks, tiles and other construction materials were sold out, and part of the space was used for other purposes. In January 1937, one of the former «Prowodnik» buildings housed a closed tennis court, built specifically for fans of this sport [29]. In the premises of «Prowodnik», also shooting could be heard - in May 1936, shooting competitions of policemen, guards and members of the army were held there [30]. The two-storey buildings with a three-storey central part at 14/16 Simana Street, where production did not take place, were rented out to the Riga City Education Board in order to accommodate the Riga City 1st Mixed Elementary School, the 5th German Basic School, the 2nd Belorussian Elementary School, the 6th Library and the 2nd Handicraft Workshop [31]. It is known that later the liquidators of the company wanted to sell these buildings. After the Second World War, in 1946, the buildings of 
«Prowodnik» were rebuilt and housed the Riga Electromechanical Factory. The majority of them, built at the end of the 19th century and at the beginning of the 20th century are still can be seen and are used for various purposes, including production.

\section{Graduates of the Riga Polytechnicum / Riga Polytechnic Institute - employees of «Prowodnik»}

The Riga Polytechnicum was founded to provide Riga, as well as the Baltic provinces with engineers. It was established in 1862, and in 1896, it was reorganized as the Riga Polytechnic Institute. As time passed by, it educated more and more engineers in different areas: architects, engineers-technologists, chemists, agronomists, commerce, engineering, roads, bridges and railway engineers. In the 1880s, there were more than fifty graduates, whereas in the 1890s, the number of graduates was close to hundred. The university reached its peak in preparation of engineers by the year 1903/1904 when 229 young engineers received diplomas [32]. Young people from different parts of Czarist Russia studied in Riga, and after studies they found work in the large Russia and abroad. Part of the engineers took various positions in Riga, including the rubber, guttapercha and telegraph accessories factory «Prowodnik».

Along with the position of Director General, which, as already mentioned, was held by Boris Wittenberg, who had not studied in Riga, the factory had four more directors [33]. Two graduates of the Department of Mechanical Engineering (until 1896 - Machine Engineering) of the Riga Polytechnicum had held those high positions - Arnold von Hertwig (1859-1928) and Artur Voegeding (1878-1936). The graduate of 1887 A. von Hertwig began working in the factory in 1895, and became its director in 1907. He continued his work during the First World War in Moscow and returned to Riga in 1919. Not wishing just to enjoy his old age and unable to find a suitable occupation in Riga, he went to St. Petersburg and rebuilt the Rubber Factory «Треугольник» («Treugolnik»/«Triangle») in accordance with the latest technological developments. A. von Hertwig's life ended in Russia, but he was buried in Riga [34].

The graduate of 1901, Artur Voegeding, first worked as a lecturer at his alma mater (1899-1903), then at the Baltic Wagon Factory in Riga (1903-1917), and during the First World War in Moscow he became the technical director of the factory «Prowodnik» (1917-1919). During the inter-war years, A. Voegeding worked as Head of the Wagon Department of the Latvian State Railways Workshops (1920-1923), at the private company of Swiss engineer R. Mantel (1923-1924), as an engineer at 
joint-stock company «Lini» (1924-1926), but at the end of his life as an engineer at Riga City Street Railways [36].

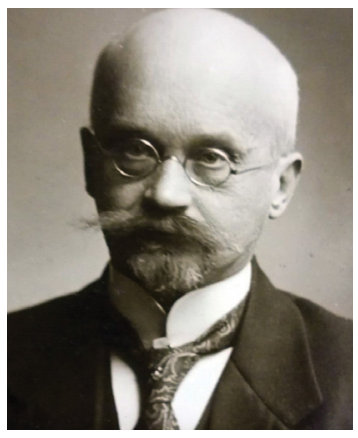

Figure 3. Technical Director of «Prowodnik» (19171919) engineer Artur Voegeding (around 1927) [35].

Karl Hans Ehmann (1859-?), the 1884 graduate of the Department of Technical Chemistry, worked as a factory technical director (18891901), and, in 1901, became a representative of «Prowodnik» in the Siberian city of Tomsk, Russia. In 1920, the Soviet authorities arrested him and he was imprisoned in a concentration camp [37]. There is no news about his fate, but he might have arrived in Estonia as an optant in 1920. K. H. Ehmann, in contrast to the ideology of communist rule, was a believer, was not a communist, and was actively involved in social work taking part in the Baltic-German Student Corporation «Fraternitas Baltica», founded at the Riga Polytechnicum in 1865. This and other student life-long organizations united their members not only with common ideas, memories of study years and with meetings, they also had an important role in the field of economics - they were involved in the work of various companies, including the «Prowodnik» factory. The Riga related German-Baltic Student Corporations were involved in entrepreneurship. Of course, the Riga Polytechnicum / Riga Polytechnic Institute had a significant role as it was possible to obtain appropriate education there. [38].

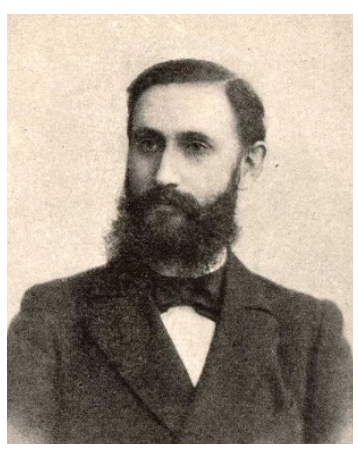

Figure 4. Karl Hans Ehmann at the beginning of the 20th century. Photo from the «Prowodnik» / RER Museum [39]. 
There were eight more RPI trained chemists - members of the student corporation "Fraternitas Baltica»- who worked in «Prowodnik». A graduate of 1882, Nikolai Pohrt (1854-?) became an employee of the factory in 1899, but a graduate of 1892, Erwin Brock (1864-?) - in 1892. In 1908, E. Brock he began to run the linseed oil production line of the factory. A graduate of 1899, Hermann Dsenne (1869-1937) began his career in the factory in 1904 as a chemist, later he was head of a department, but his study fellow Friedrich Reinfeld (1872-?) worked as a chemist for three years - from summer 1902 to November 1905. From September 1902 to August 1903, Wolfgang Wachtsmuth (1876-1964), a 1903 graduate, joined the factory as a chemistry specialist. A 1895 graduate Ernst von Reusner (1869-1897) worked as a chemist (1896-1897) for a short time because he fell ill with typhus and died. A graduate of 1896, Georg Boustedt (1867-?), right after studies started working in the cable division, later in other divisions, but in 1898, he began to work at another factory. His study mate James Haken (1864-?) was working outside the territory of the present Latvia, but in 1905, he arrived in Riga and joined factory «Prowodnik». A graduate of the Department of Agriculture (1899) Edgar von Pickardt (1876-1973) worked in the factory for a short time - from November 1903 until September 1904. In addition, there were more employees coming from «Fraternitas Baltica», who had not received university diplomas in Riga. Johannes Hausen (1864-?) who had studied mechanics and had taken a laboratory course in technical mechanics in Dresden with the well-known Professor Karl Ernst Hartig (1836-1900) and practiced cotton production, becoming as an Assistant Director of «Prowodnik». In 1899, Theodor Kittel (1862-?), former student of Machine Engineering and Engineering Department, a graduate of the Technical School of Mittweida in Saxony, and Hugo Kleinberg (1866-?) who had studied at the Department of Agriculture (1886-1892) [40] started to work at the factory in Sarkandaugava. By the way, H. Kleinberg became Technical Director of the above mentioned newly created rubber factory «Kontinents» in 1923.

The aforementioned A. fon Hertvig came from another Baltic-German Student Corporation «Concordia Rigensis» (1869), founded at the Riga Polytechnicum. The following graduates of RPI had been Heads of the "Prowodnik» factory divisions: in 1912-1914 - a graduate of the Department of Mechanical Engineering (1911) of RPI E. Thiel (1886-?); in 1904-1914 - a graduate of the Department of Engineering Chemistry (1981) of RPI Karl Loewende (1860-?); and in 1909-1914 - graduates of the Department of Chemistry (1908) Theodor Giese (1880-1915) and Woldemar Ptaschnikow (1877-?). A graduate of the Department of Mechanical Engineering (1899) Wilhelm Mackprang (1876-?) worked as an engineer, but former student Julius Strauss (1875-?) was an accountant 
at the «Prowodnik» branch office in Samara [41]. Another corporate member, a graduate of the Department of Engineering (1893) of RP and Associate Professor of RPI (1906-1918) Oskar Hackel (1864 - 1920) was a technical advisor from 1906 [42].

In addition, there were other former "polytechnicans» such as a graduate of the Department of Trade of RPI (1898) Nikolai (Nota) Ginsburg (1873-?) - the factory's authorized officer in St. Petersburg (since 1900), a graduate of the Department of Mechanical Engineering (1914) of RPI, rocket constructor and pioneering astronaut Friedrich Zander (18871933); former students Pavel Fedotovsky (Павел Федотовский; 1886-?) who was a correspondent from 1910, William Hein (1854-?) [43], Erich Lange (1878-?), and Nikolai Boehnke (1881-?), who had been a factory accountant and controller in Riga, Samara, Tashkent, and St. Petersburg since 1908 [44]. The positions of Head of the division (1914-1915) and of Technical Director (1915-1919) were held by civil engineer Maksimiliāns Krastinšs (1883-?), a graduate of the Technical University of Braunschweig (1912), who started his studies at RPI, but apparently due to the events of the 1905 revolution did not return to the institute and obtained a university diploma in Germany [45].

The «Prowodnik» division in Riga and Moscow (1905-1918) was headed by Arnold Schilinzky (1878-1927) - a graduate of the Department of Chemistry (1906), who after the establishment of the Republic of Latvia worked as a tutor in mathematics, but at the end of his life was a teacher and an inspector of Riga City German High School (1922-1927) [45].

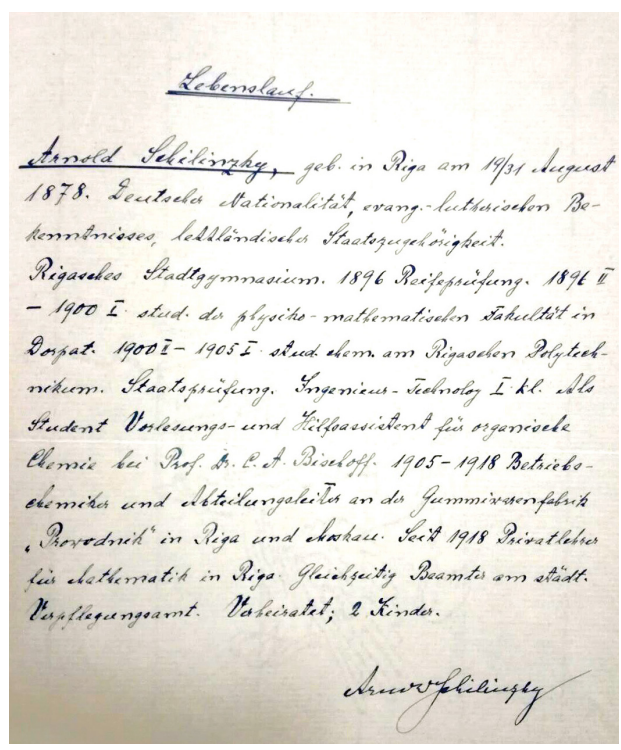

Figure 5. Arnold Schilinzky's autobiography (around 1919) [46]. 


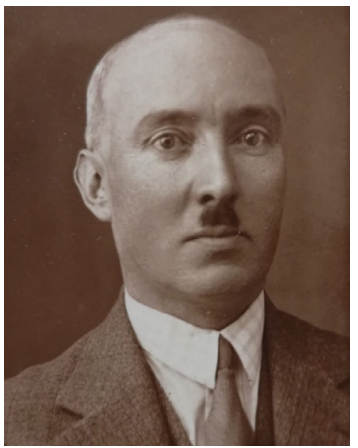

The Activities

of Factory

«Prowodnik»

in Riga and its

Employees -

Graduates

of the Riga

Polytechnicum /

Riga Polytechnic

Institute

Figure 6. Nikolai Brinckenhoff (around 1927) [48].

It is known that the graduate of the Department of Trade / Commerce (1908) Nikolai Brinckenhoff (1885-?) immediately after graduating from RPI, began working as an accountant and correspondent in «Prowodnik». He was also the Director of the factory during the inter-war period [47].

\section{Conclusions}

Factory «Prowodnik» at the end of the 19th century and at the beginning of the 20th century was the heart of Sarkandaugava and was the most characteristic company in this district of Riga. Many Latvians who came from rural areas to Riga, and engineers, at least three dozen RP / RPI graduates and former students, mostly German-speaking, started their work there. The factory in Sarkandaugava was just as important as the "Baltic Wagon Factory» in Grīzinkkalns. Later, in Sarkandaugava also the "Aldaris» brewery played an important role, but «Prowodnik» operated on a much wider scale, meeting the demands for its produce of consumers not only in Latvia but also in the Czarist Russian and partly also in foreign countries. There were many different companies operating on the factory premises. In the autumn of 1940, it was the mechanical company «Sorobins» [49], during the Second World War - the aircraft repair workshop [50], from 1946 - the Riga Electromechanical Building Factory $(R E R)$, which had employed and continues to employ the graduates of Riga Technical University (until 1990 - Riga Polytechnic Institute), including one of the authors of the article - Olegs Šapovalovs.

Engineers with a university education obtained in Riga have made an important contribution to the operation and development of the factory. This is reflected in the exposition of the factory "Prowodnik» / Riga Electromechanical Building Factory Museum. 


\section{LIST OF SOURCES AND LITERATURE}

[1] «Prowodnik» company, Riga. Riga [1907], p. 3.

[2] Zemgalietis V. Latvijas rūpniecības jaunie ceḷi. Zemgales Balss, 1937, No. 60, 4. lpp.

[3] Latvijas Valsts vēstures arhīvs (turpmāk - LVVA) 1773. f., 1. apr., 982. l., 13. lp

[4] «Prowodnik» company, Riga. Riga [1907], p. 4, 13, 20.

[5] LVVA 1773. f., 2. apr., 9. 1., 6. lp.

[6] Cimmermanis M. Mūsu gumijas rūpniecība. Ekonomists, 1929, No. 7, 1. lp.

[7] The Prowodnik Works at Riga. Pieejams: http://archive.commercialmotor.com/article/24th-september-1908/3/the-prowodnik-works-at-riga [skatīts: 24.01.2018]

[8] Shapovalov O. Roman s «Provodnikom». Riga, 2017, s. 8.

[9] Zemgalietis V. Latvijas rūpniecības jaunie cel̦i. Zemgales Balss, 1937, No. 60, 4. lpp.

[10] Streiku kustība. Dzimtenes Vēstnesis, 1913, No. 162, 3. lpp.

[11] Shapovalov O. Roman s «Provodnikom». Riga, 2017, s. 125

[12] Rīgas zinas. Balss, 1906, No. 96, 2. lpp.

[13] Lokales. Libausche Zeitung, 1914, No. 226, S. 3.

[14] «Prowodnik» company, Riga. Riga [1907], p. 4.

[15] Veiss E. A. J. Rīgas Politechniskais institūts 100 gados. Technikas Apskats, 1962, No. 35, 4. lpp.

[16] LVVA 1773. f., 1. apr., 3. l., 325. lpp.

[17] «Provodṇika» atjaunošana. Latvijas Tirgotājs, 1921, No. 5, 6. lpp.

[18] LVVA 1773. f., 1. apr., 1. 1., 1. lp.

[19] Mūsu rūpniecības atjaunošana. Valdības Vēstnesis, 1921, No. 119, 2. lpp.

[20] «Provodnik». Segodna, 1921, No. 291, 1. lpp.

[21] Darba dzīve. Krievijas Cīna, 1923, No. 77, 4. lpp.

[22] Latvijas gumijrūpniecība. Latvijas Tirgotājs, 1930, No. 1/2, 52.lpp.

[23] «Provodnnika» atklāšana atlikta. Amerikas Atbalss, 1921, No. 43, 2. lpp.

[24] «Prowodnik»in schweizerischen Händen. Libausche Zeitung, 1924, No. 266, S. 2.

[25] Rūpniecība atjaunojas. Krievijas Cīna, 1924, No. 26, 3. lpp.

[26] LVVA 7064. f., 1. apr., 2. l., 12.-13. lp.

[27] Kiesners A. Lielais ugunsgrēks Sovtorgflota linu noliktavās - bij. Provodñika fabrikā. Ugunsdzēsējs, 1930, No. 6, 439. lpp.

[28] Krievu-franču gumijas, guttaperčas un telegr. pied. fabr. s-ba zem firmas «Provodņiks» likvidācija. Ekonomists, 1935, No. 22, 873. lpp.

[29] Jaunas telpas tenisa spēlei. Jaunākās Zinnas, 1937, No. 19, 3. lpp.

[30] Labi sasniegumi LSOS pārbaudes sacīkstes. Rīts, 1936, No. 144, 4. lpp.

[31] Gaisa satiksmi Rīga-Liepāja atklās nākamā pavasarī. Rìts, 1935, No. 204, 1. lpp.

[32] Festschrift zum fünfzigjährigen Jubiläum des Rigaschen Polytechnischen Instiuts, 1862-1912. Riga: W. F. Häcker, 1912, Tab. 1. 
[33] LVVA 1773. f., 1. apr., 982. l., 13. lp.

[34] Arnold von Hertwig. Rigasche Rundschau 1928, 1928, No. 50, S. 7.

[35] LVVA 2996. f., 6. apr., 1612. l., 3. lp.

[36] Rīgas Politechnikums, 1862.-1919. g. Album Academicum (1912.-1919. g.). Rīga: Latvijas Universitātes Studentu grāmatnīcas izdevums, 1938, 289. lpp.

[37] Spiski shertv. Pieejams: http://lists.memo.ru/d38/f85.htm [skatīts: 21.01.2018].

[38] Cerūzis, R. Vācu faktors Latvijā (1918.-1939.): politiskie un starpnacionālie aspekti. Promocijas darbs. Rīga: LU Vēstures un filozofijas fakultāte, 2002, 310. lpp.

[39] Karls Hans Ēmans, 21. gs. sākumā.«Provodṇik»/RER muzeja krājums.

[40] Rosenkranz, M., Stieda, E. (Hrs.). Album der Landsleute der Fraternitas Baltica, 1865-1910. Riga, 1910, S. 60, 68, 69,83, 84, 91, 94-96, 104, 117, 122, 123.

[41] Concordia Rigensis: 29.11.1869-29.11.1969 : Festschrift : Chronik, Album, Statistisches. Hamburg: Philisterverband der Concordia Rigensis, 1969, S. 86, 90, 104, 112, 116, 121.

[42] Album Academicum des Polytechnikums zu Riga, 1862-1912. Riga: Jonck \& Poliewsky, 1912, S. 169.

[43] Neujahr 1908. Rigasche Zeitung, 1908, No. 1, S. 8.

[44] Album Academicum des Polytechnikums zu Riga, 1862-1912. Riga: Jonck \& Poliewsky, 1912, S. 322, 497, 512, 567.

[45] LVVA 1303. f., 3. apr., 19. l., 145. lp.

[46] LVVA 1632. f., 1. apr., 20784. l.

[47] LVVA 1773. f., 1. apr., 3. l., 3. lp.

[48] LVVA 3234. f., 33. apr., 24057. 1.

[49] Var pieteikties traktoru vadītāju kursos. Cīna, 1940, No. 104, 10. lpp.

[50] Elmārs T. Sarkandaugavā. Cīna, 1944, No. 66, 2.lpp.

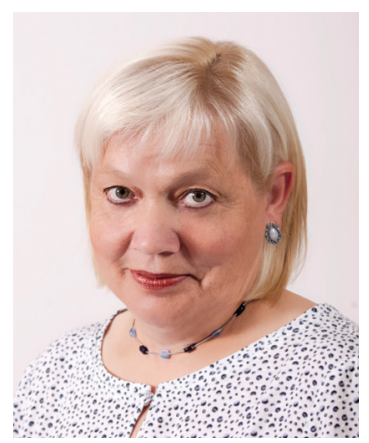

ALİDA ZIGMUNDE, Dr. paed., has been a Specialist at the Museum of Riga Technical University since 1989. From 2007 to 2015, she was a Senior Researcher. She is currently a Professor at the Institute for Humanities and Head of the Department for Historic Research and Scientific Publications of the RTU Research Centre for Engineering History. Her main academic interests include the history of pedagogy in Europe, the history of the institutions of education and of private schools, and the history of pedagogy of universities, history of engineering sciences and universities.

Address: 1 Kronvalda Boulevard, Riga, LV-1010, Latvia

Phone: +37129869642

E-mail: alida.zigmunde@rtu.lv 


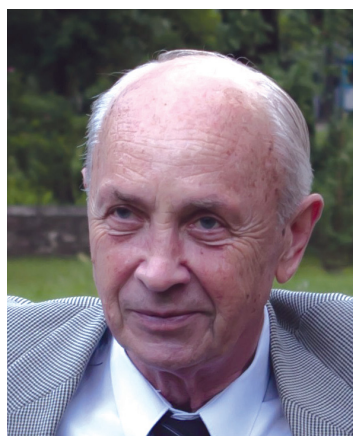

OḶEGS ŠAPOVALOVS, Dr. sc. ing., graduated from RPI in 1959, directed to work at Riga Electromachine Building Factory $(R E R)$. Previously he had been the team leader, SKB chief engineer, deputychief engineer of RER, director of privatization. He received a degree of Candidate of Science in 1968, and the Dr.sc ing. degree in 1992 . He was a docent at RPI in 1993. Lately he is engaged in the activities of the «Provodnik» / RER museum. He has written the book «Roman with «Provodnik»» in 2017.

Address: 15 Hāpsalas Street 15, Flat 98, Riga, LV-1005, Latvia

Phone: +37120396320

E-mail: oleg_shapovalov@inbox.lv

Alīda Zigmunde, Oḷegs Šapovalovs

\section{Fabrikas «Provodṇik» darbība Rīgā un tās darbinieki - Rīgas Politehnikuma / Rīgas Politehniskā institūta absolventi}

Rakstā dots pārskats par 1888. gada jūnijā Rīgā, Sarkandaugavā, nodibinātā krievu un franču kopuzñēmuma - gumijas, gutaperčas un telegrāfa piederumu fabriku sabiedrības «Provodñik» darbību. Pirms Pirmā pasaules kara «Provodñik» kḷuva par vienu no četrām lielākajām gumijas fabrikām pasaulē. 1915. gadā fabriku evakuēja uz Maskavu, 1918. gadā uzñēmumu nacionalizēja. 1921. gadā akcionāri nolēma fabrikas bijušajās telpās atjaunot «Provodṇik» darbību, bet situācija bija mainījusies. Tā vairākus gadus darbojās kā kokapstrādes rūpnīca (1925-1935), bet nekad nesasniedza tādu uzplaukumu kā 19. gadsimta beigās un 20. gadsimta sākumā. 20. gadsimta 30. gadu beigās likvidēta. Nozīmīgu ieguldījumu «Provodṇik» darbā un attīstībā devuši Rīgas Politehniskā institūta absolventi, kuri apzināti, veicot dokumentos balstītu pētījumu.

Atslēgas vārdi. «Provodṇik», Rīgas Politehnikums, Rīgas Politehniskais institūts, absolventi rūpniecībā.

Алида Зигмунде, Олег Шаповалов

\section{Работа предприятия «Проводник» в Риге и его персонал - выпускники Рижского политехникума/Рижского политехнического института}

В статье приводится обзор деятельности созданного в 1888 году в Риге на Саркандаугаве русско-французского совместного предприятия по изготовлению резиновых, гуттаперчевых и телеграфных изделий товарищества «Проводник». До Первой мировой войны оно стало одним из четырех крупнейших в мире резиновых фабрик. В 1915 году фабрику эвакуируют в Москву, в 1918 году национализировали. В 1921 году акционеры решили в Латвии восстановить работу бывшего «Проводника», но ситуация изменилась. Многие годы фабрика проработала как 
деревообрабатывающее предприятие (1925-1935), но никогда не достигло такого развития, как в конце 19-го, начале 20-го веков. В конце 30-х годов предприятие ликвидировано. Существенный вклад в работу и развитие «Проводника» внесли выпускники Рижского политехнического института, о чем узнали авторы статьи из документов при проведении исследований.

Ключевые слова: «Проводник», Рижский политехникум, Рижский политехнический институт, выпускники на производстве.
The Activities of Factory «Prowodnik» in Riga and its Employees -

Graduates of the Riga Polytechnicum / Riga Polytechnic Institute 